\title{
Transcriptomic analysis to reveal the differentially expressed miRNA targets and their miRNAs in response to Ralstonia solanacearum in ginger species
}

Mohandas Snigdha and Duraisamy Prasath*

\begin{abstract}
Background: Bacterial wilt is the most devastating disease in ginger caused by Ralstonia solanacearum. Even though ginger (Zingiber officinale) and mango ginger (Curcuma amada) are from the same family Zingiberaceae, the latter is resistant to $R$. solanacearum infection. MicroRNAs have been identified in many crops which regulates plant-pathogen interaction, either through silencing genes or by blocking mRNA translation. However, miRNA's vital role and its targets in mango ginger in protecting bacterial wilt is not yet studied extensively. In the present study, using the "psRNATarget" server, we analyzed available ginger (susceptible) and mango ginger (resistant) transcriptome to delineate and compare the microRNAs (miRNA) and their target genes (miRTGs).

Results: A total of 4736 and 4485 differential expressed miRTGs (DEmiRTGs) were identified in ginger and mango ginger, respectively, in response to $R$. solanacearum. Functional annotation results showed that mango ginger had higher enrichment than ginger in top enriched GO terms. Among the DEmiRTGs, 2105 were common in ginger and mango ginger. However, 2337 miRTGs were expressed only in mango ginger which includes 62 defence related and upregulated miRTGs. We also identified 213 miRTGs upregulated in mango ginger but downregulated in ginger, out of which 23 DEmiRTGS were defence response related. We selected nine miRNA/miRTGs pairs from the data set of common miRTGs of ginger and mango ginger and validated using QPCR.

Conclusions: Our data covered the expression information of 9221 miRTGs. We identified nine miRNA/miRTGs key candidate pairs in response to $R$. solanacearum infection in ginger. This is the first report of the integrated analysis of miRTGs and miRNAs in response to $R$. solanacearum infection among ginger species. This study is expected to deliver several insights in understanding the miRNA regulatory network in ginger and mango ginger response to bacterial wilt.
\end{abstract}

Keywords: Bacterial wilt, Ginger, miRNA, Mango ginger, Ralstonia, Target genes

\section{Background}

India is rich in spices and has been regarded as the "Spice Bowl of the World". Ginger (Zingiber officinale Rosc.), the major spice and medicinal crop, is cultivated mainly in

*Correspondence: prasath.d@icar.gov.in

ICAR-Indian Institute of Spices Research, Kozhikode, Kerala 673012, India tropical and subtropical regions of India. The rhizomes contain several bioactive compounds used as a flavouring agent, herbal medicine and is also employed in the perfume industry $[1,2]$. India is the major producer of ginger, accounting for $31 \%$ of the world production [3]. Several reports have been published regarding the crop loss due to bacterial wilt caused by Ralstonia solanacearum [2]. Bacterial wilt is considered as a major disease especially 
in regions with warm climates [4]. India has crossed yield losses of more than $50 \%$ due to this infection [5]. Around the world, the $R$. solanacearum, a soil-borne bacterium, causes bacterial wilt in many plant families such as tomato, potato, pepper, peanut, banana and eggplant [6]. This gram-negative bacterium infects plants through axils of secondary roots, which later invades cortex and then colonizes in the xylem vessels which causes wilt symptoms and death [7].

Many recent studies have increasingly concentrated on host plant resistance than traditional chemical treatments, which seems to be more powerful and economical in controlling bacterial wilt infection [8]. Several enhanced resistance varieties of potato, tomato, peanut, eggplant, and banana have been successfully generated by transforming the resistant gene to the plant $[7,9]$. Research has been carried out to identify the resistance source to Ralstonia induced bacterial wilt in ginger. In a study, the ICAR-Indian Institute of Spices Research, Kozhikode, Kerala, reported mango ginger (Curcuma amada Roxb.) from the ginger family Zingiberaceae, with a high level of resistance against bacterial wilt. Comparative transcriptomics of ginger and mango ginger during bacterial wilt has resulted in identifying a considerable number of candidate genes [10].

Earlier reports states that microRNAs (miRNAs) are hypersensitive to diverse physiological processes such as abiotic or biotic stress $[11,12]$. miRNAs which are approximately 21-nucleotide noncoding RNAs, serve a crucial role in post-transcriptional gene regulation by degrading target mRNAs in plants. Previous researchers have identified several plant miRNAs and their targets, which are related to biotic stress. This supports that miRNAs are crucial to the stress response of plants [13]. Thus far, the miRNA expression profiles of ginger under bacterial stress conditions have rarely been reported. Efforts to identify bacterial wilt responsive miRNAs and determine their expression patterns would improve our understanding of their stress adaptation functions.

Several researchers reported that pathogen attack in plants induce numerous miRNAs and later control and contribute towards the reprogramming of gene expression [12-19]. It was reported that during wheat-stripe rust infection, several variants of known miRNAs and 163 candidate novel wheat miRNAs were differentially expressed [12]. Much research has been carried out to overexpress significant miRNAs to enhance disease resistance in susceptible plants. Overexpressing miR319b in rice found to be a positive regulator of the rice defence response against the blast disease [14]. Differential expression of miRNAs was observed in wheat and barley after infection with powdery mildew $[15,16]$. The introduction of artificial miRNA has been carried out in several plants against viral infection, such as wheat, maize, tomato, and grape wine [17-19].

This study employed already available transcriptome to investigate and elucidate a detailed and in-depth characterization of miRTGs and their expression in ginger (susceptible) and mango ginger (resistant) transcriptome during $R$. solanacearum infection. We identified miRTGs and their known miRNAs involved in defence-related, plant-pathogen interaction and disease resistance. Our results provided valuable information to reveal the molecular mechanism of miRNAs and their targets in resisting mango ginger against $R$. solanacearum infection.

\section{Results}

\section{Identification of miRTGs}

Already available ginger and mango ginger RNA-Seq data from our lab was utilized to reconstruct transcriptome de novo. A total of 80,496,326 and 66,561,960 raw reads, accounting approximately for mango ginger and ginger, respectively, were generated (Table 1 ). The mango ginger assembly was represented by 307,952 contigs with an average of $845.32 \mathrm{bps}$, while the ginger assembly was represented by 303,878 contigs with an average contig size of 692.32 bps. The N50 for mango ginger and ginger with de novo assemblies were 1256 and 1005, respectively. These assembled contigs were further used to identify known miRTGs. After carefully considering the alignment results, we located a total of 4736 and 4485 DEmiRTGs (significant $p$-value $<=0.05$ and having functional annotation) in ginger and mango ginger, respectively (Fig. 1).

\section{Identification of miRNAs from miRTGs}

The 'psRNATarget' server was utilized to map miRNAs from miRTGs. Each miRTG provided a varying number of miRNAs. In ginger, maximum miRNAs (1193) were identified for the target, miRTG UBC24_ARATH. Among ginger miRTGs, 271 did not show any corresponding miRNAs. In mango ginger, miRTG NFYA7_ARATH

Table 1 Assembly summary of transcripts of mango ginger and ginger

\begin{tabular}{lll}
\hline & Mango ginger & Ginger \\
\hline Number of reads & $80,496,326$ & $66,561,960$ \\
Average read length & 100 & 100 \\
Average GC per reads & 44 & 48 \\
Number of contigs & 307,952 & 303,878 \\
Mean contig length & 845.32 & 692.32 \\
Maximum contig length & 15,525 & 23,113 \\
N50 & 1,256 & 1,005 \\
N100 & 201 & 201 \\
\hline
\end{tabular}




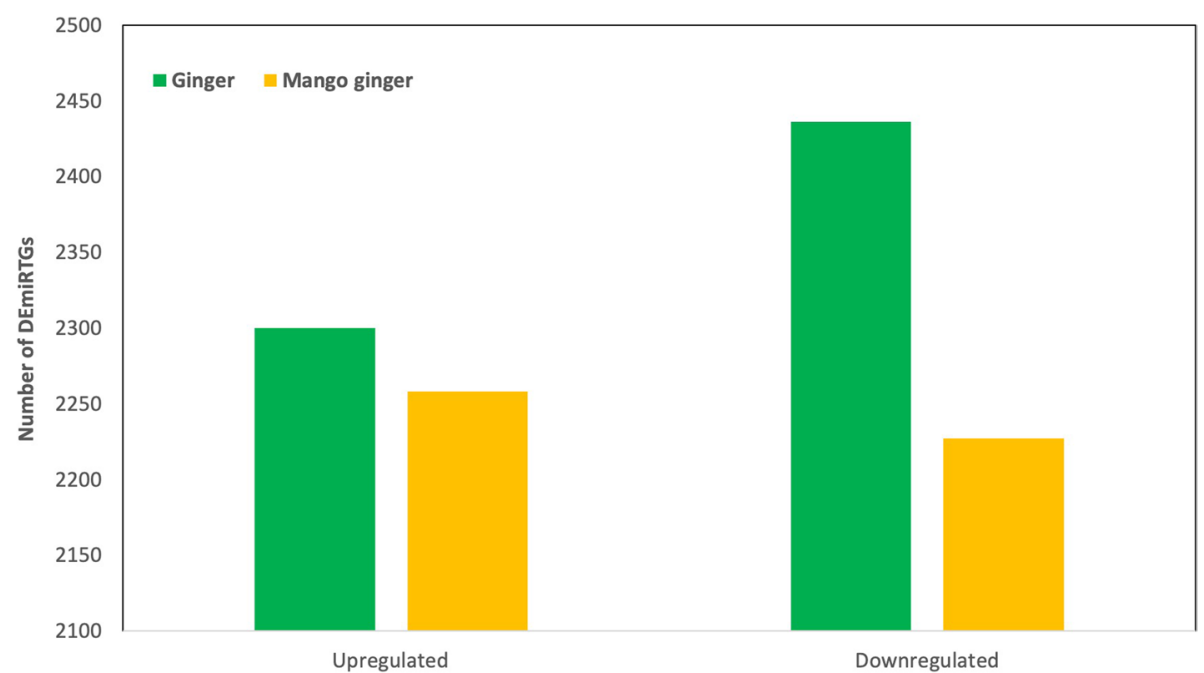

Fig. 1 Numbers of differentially expressed total miRTGs in response to bacterial wilt in ginger and mango ginger

had the maximum number of miRNAs (320). No miRNAs were identified for 315 mango ginger miRTGs. Each miRTGs had targets for several miRNAs and vice versa and they combined to form a complex network (Fig. 2; Supplementary data 1).

\section{Differential expression of miRTGs}

We identified 4736 differentially expressed miRTGs in ginger (susceptible), out of which 2300 were upregulated and 2436 were downregulated. In mango ginger (resistant), out of 4485 DEmiRTGs, 2258 were upregulated,

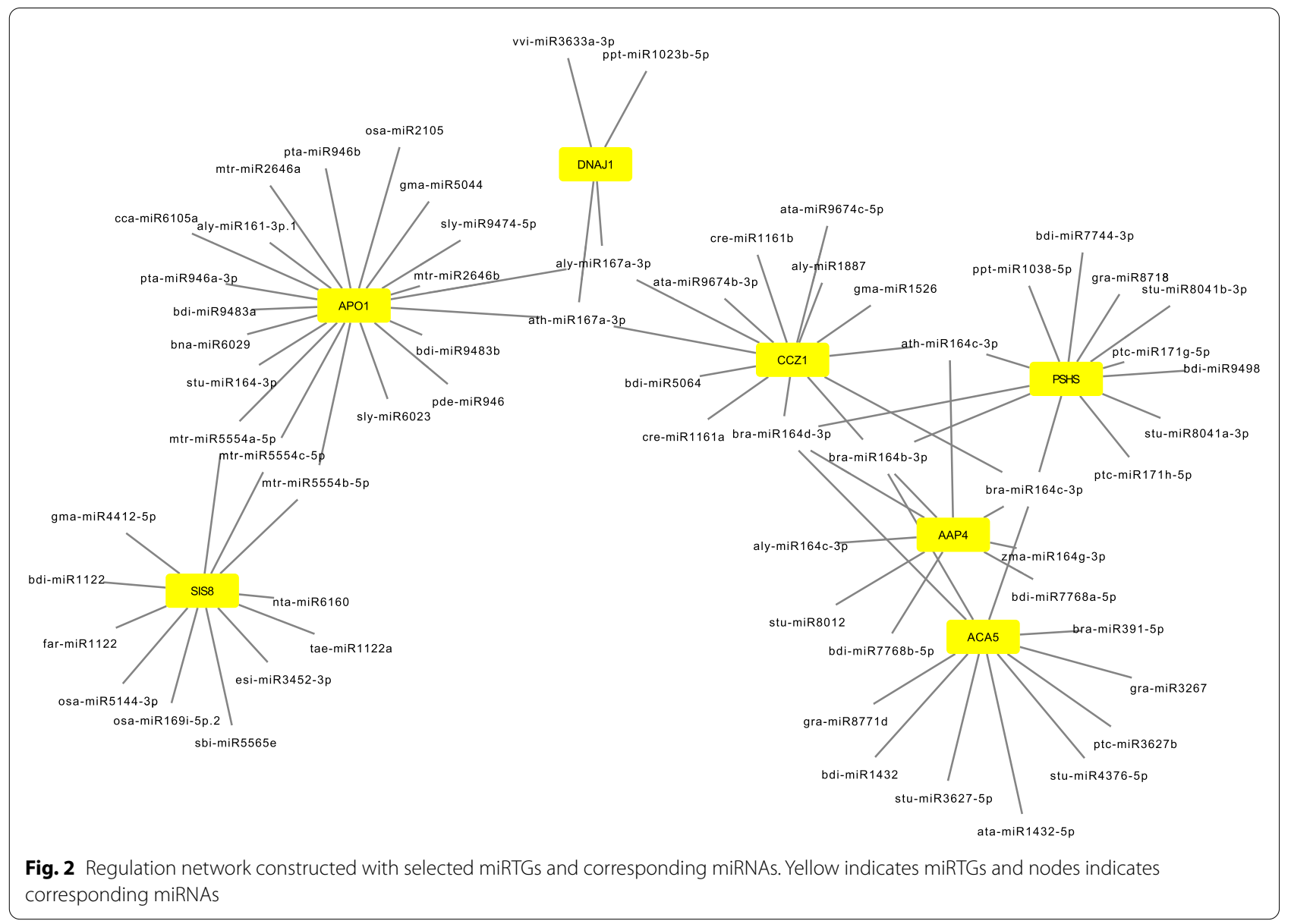


and 2227 were downregulated (Fig. 1). Among the total 9921 DEmiRTGs in response to $R$. solanacearum, 2105 were common in ginger and mango ginger. The common DEmiRTGs revealed, 965 upregulated and 1140 downregulated in ginger and 776 upregulated, and 1329 downregulated in mango ginger (Fig. 3). When compared with ginger, 2337 miRTGs were expressed only in mango ginger. Moreover, we also observed 215 miRTGs upregulated in resistant mango ginger but downregulated in susceptible ginger (Fig. 4). Nine miRTGs were selected based on their function and fold change from the common miRTGs differentially expressed in both plants. Primers were designed for each target genes and its miRNAs (Tables 2 and 3). The real-time PCR analysis of these miRTGs genes and their miRNAs revealed their differential expression among the two ginger species.

\section{GO and KEGG pathways of DEmiRTGs}

Gene ontology (GO) analysis of DEmiRTGs was performed and grouped into three categories: biological process, cellular component, and molecular function. In the biological function category "defence response" represented the top term in ginger and mango ginger. The most abundant terms in cellular component category were "membrane" in ginger and mango ginger. In the molecular function, the GO term "ATP binding" was enriched in ginger and mango ginger (Fig. 5).

The GO analysis of upregulated DEmiRTGs expressed exclusively in mango ginger showed maximum enrichment in defence response (120), out of which 29 were related to "defence response in bacterium". Among the 2105 common miRTGs, 45 and 71 were "defence response" GO terms upregulated in ginger and mango ginger, respectively. There were 213 miRTGs which were upregulated in mango ginger but downregulated in ginger. Among them $23 \mathrm{GO}$ terms were related to "defense response", which was the highest among all GO terms. Also, $10 \mathrm{GO}$ terms were related to "defence response in bacterium" (Table 4).

The top 10 enriched pathways regulated by Ralstoina are summarized in Fig. 6. The most enriched pathways were related to protein and amino acid pathways such as "protein modification" and "protein ubiquitination". Interestingly, among the top 10 enriched pathways, we observed that the number of DEmiRTGs in mango ginger was more than ginger in the carbohydrate degradation and glycolysis pathways. Thus, indicating the difference and significance of carbohydrate metabolism in giving resistance against bacterial wilt.

\section{Validation and correlation analysis of miRTGs expression profiles and their miRNAs}

To specify the roles of miRNAs in response to bacterial wilt, the expression profiles of nine miRNAs and miRTGs common in both ginger species were analysed.

The qPCR analysis validated nine selected miRNA target genes (4CLL1, ABCC5, PRT6, RPS2, FRS6, AAP4, WRKY19, ABCG11 and DNAJ1) and demonstrated their differential expression in leaf and rhizome tissues of both ginger and mango ginger during bacterial wilt infection. Among the nine miRTGs, seven were upregulated in leaves and eight in rhizome tissues of ginger. In mango ginger miRTGs, six in leaves and seven in rhizome were upregulated. Among the miRTGs, four (4CLL1, ABCC5, PRT6 and RPS2) showed upregulation in both the tissues

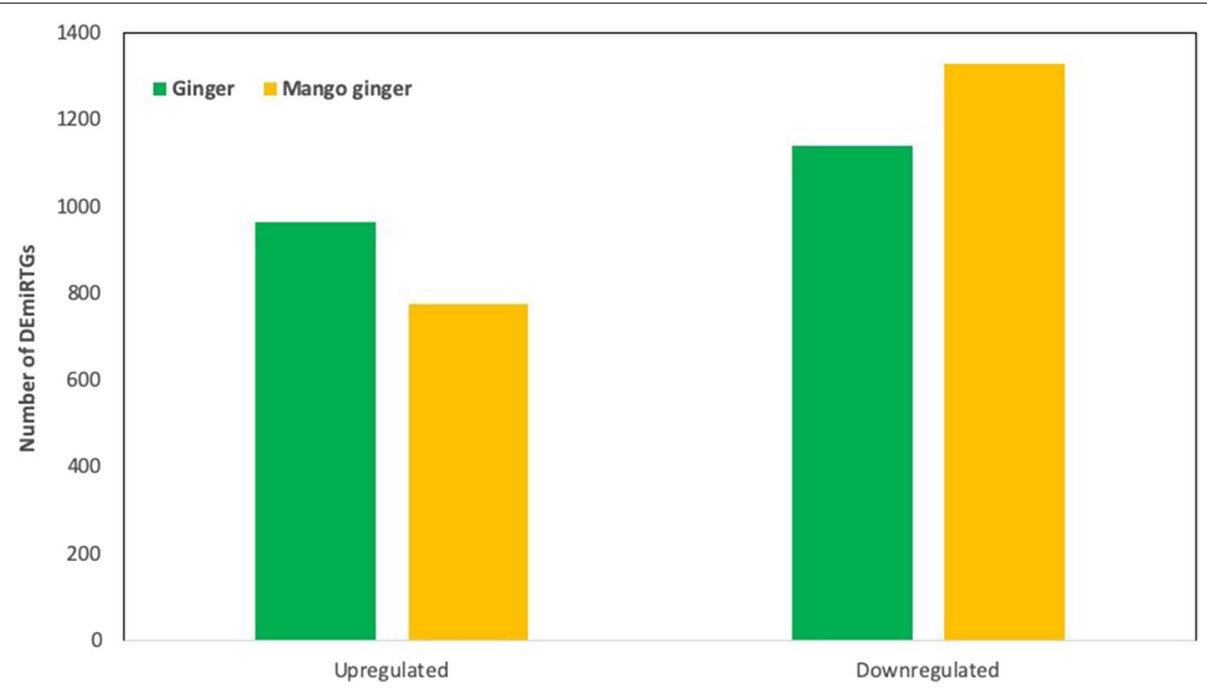

Fig. 3 Numbers of differentially expressed common miRTGs in response to bacterial wilt in ginger and mango ginger 


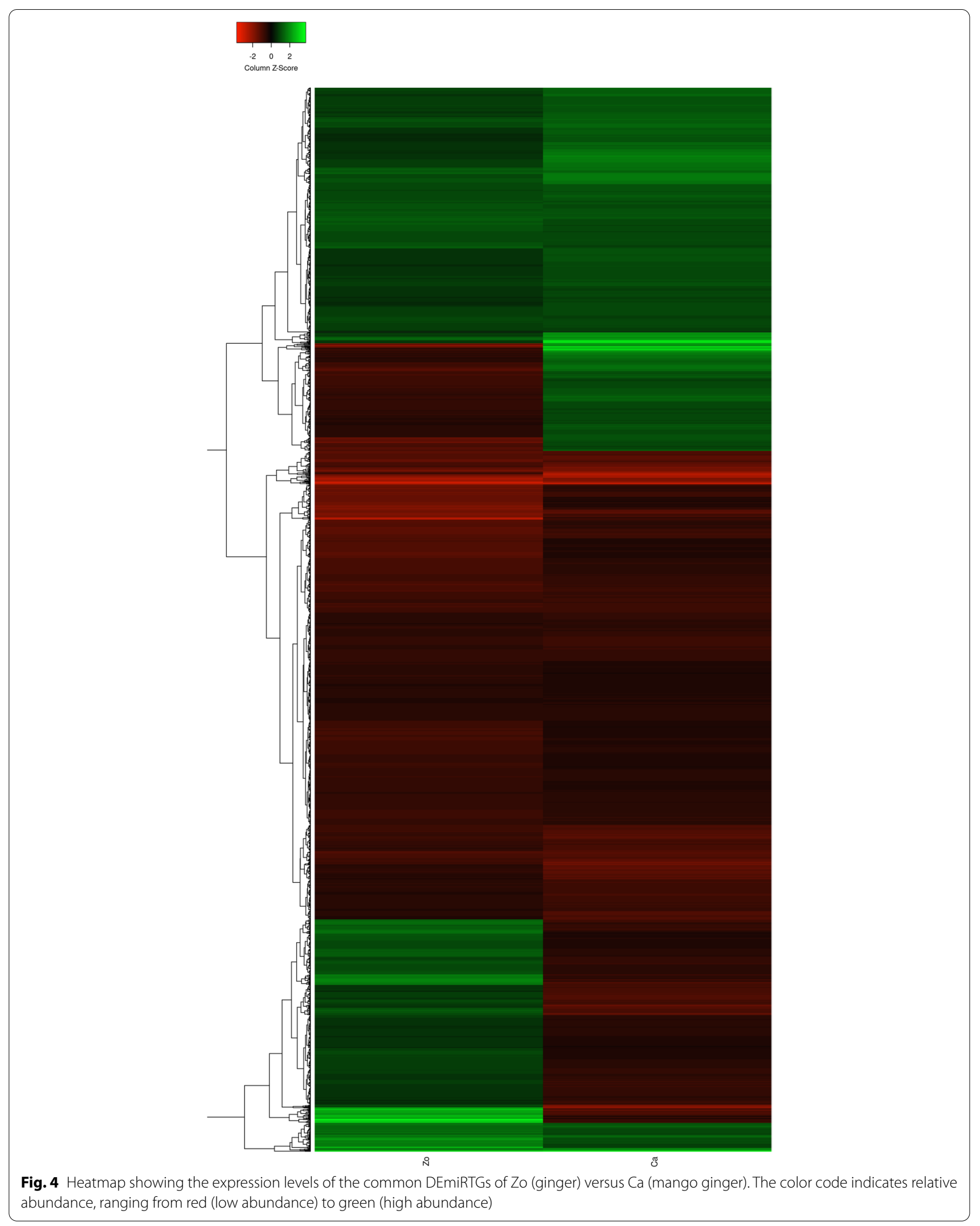


Table 2 Primer designed for target genes to perform qPCR experiments

\begin{tabular}{|c|c|}
\hline miRTGs & Primer sequence \\
\hline zO-PRT6 forward & CTTCGGCGTGCTTATTGGAA \\
\hline zo-PRT6 reverse & CCATCGAGGTAGCTGGACAT \\
\hline zO-FRS6 forward & CCAGAGCCCAAGTATCGGAA \\
\hline zo-FRS6 reverse & CAGGGTGGTTGTGGTCAATG \\
\hline zO-RPS2 forward & TTGCTCGCTTCACTGAGTTG \\
\hline zo-RPS2 reverse & GCCGCTTCAATCCTTCCAAT \\
\hline Zo-WRKY19 forward & ACCAAGAGTGCAGAAGGTCA \\
\hline Zo-WRKY19 reverse & ATGTGCCTTGCAGAAATGGG \\
\hline zo-ABCC 5 forward & CCAGCTAAGAGACGCTGAGA \\
\hline zo-ABCC5 reverse & ACGCAGATACCAAAGGCAAC \\
\hline zo-4CCL1 forward & СTTCTCTCCTCGCGTCTGAT \\
\hline zo-4CLL1 reverse & AGCCGGAACTAGCTATCGTC \\
\hline zo-DNAJ1 reverse & ATGCCCTGAAGGAGGGAATG \\
\hline zo-DNAJ1 forward & ACTTCCTCCACCTCCAAAGG \\
\hline zo-AAP4 forward & TTGTCATCCACCTTGTCGGA \\
\hline zo-AAP4 reverse & GGGTGATGAACTCGCTCTTG \\
\hline zo-ABCG11 forward & GGAACGGTGTTGGATTCAGG \\
\hline zo-ABCG11 reverse & TCAGCAGCCTTAGCCAGTAG \\
\hline ca-PRT6 forward & ATGCATGCTTGGTGAGTCTG \\
\hline ca-PRT6 reverse & GCCTGCCCATTGTTCTTAGG \\
\hline ca-FRS6 forward & CCATCATGGCCAGTTGGTTT \\
\hline ca-FRS6 reverse & TCAGTAATGAGGGCCTTGGG \\
\hline ca-RPS2 forward & GGGAACCTAGCCCTCCAAAT \\
\hline ca-RPS2 reverse & CGTATCCAGCTTCACGCAAT \\
\hline ca-WRKY19 forward & AGGCCGGACTAGTTACTGTG \\
\hline ca-WRKY19 reverse & CACAATGTTTGCCACCTCCA \\
\hline ca-ABCC 5 forward & GCTGCTCCTCTTCTTCCTGA \\
\hline ca-ABCC5 reverse & CAAACCGACCGAAACCTGAA \\
\hline ca-4CLL1 forward & CGTCAAGTTCAACGGACCTC \\
\hline ca-4CLL1 reverse & TAGCCGGAACTAGCAATCGT \\
\hline ca-DNAJ1 forward & ACGAGATGGTGCTGACGTAT \\
\hline ca-DNAJ1 reverse & AGTATTGTCCTGGCTGCACT \\
\hline ca-AAP4 forward & ATCTCTGCGGACTCATCCAG \\
\hline ca-AAP4 reverse & GGCCTTTCTCATGGAAGCAG \\
\hline ca-ABCG11 forward & CTACTGGCTAAGGCTGCTGA \\
\hline ca-ABCG11 reverse & AGACGAATGAAGCACATGCC \\
\hline Actin forward & TAGGTGCCCAGAGGTTCTATT \\
\hline Actin reverse & ACCGCTAAGCACCACATTAC \\
\hline
\end{tabular}

of ginger and mango ginger. The miRTGs, FRS6 and WRKY19, were upregulated in ginger but downregulated in mango ginger, whereas AAP4 showed downregulation in ginger and upregulation in mango ginger. The ABCG11 was upregulated in all three samples except ginger leaves. In DNAJ1, an upregulation was observed in all samples except mango ginger leaves (Table 5 and Fig. 7).

Stem-loop PCR was performed to analyse the expression of nine miRNAs (ath-miR1886, mtr-miR5261,
osa-miR169, gra-miR482, ppt-miR1223, mtr-miR164, aly-miR398, gma-miR4415 and ath-miR167). Among them, mtr-miR164 and ppt-miR1223 showed upregulation in both the tissues of ginger and mango ginger. However, ppt-miR1223 downregulated in ginger rhizome after $8 \mathrm{~h}$ post-inoculation. The miRNAs, gra-miR482 and ath-miR167 upregulated in both tissues of mango ginger but downregulated in ginger in all the time intervals. Ath-miR1886 and aly-miR398 were upregulated only in mango ginger rhizome post inoculation (Fig. 7).

The correlation analysis was carried out using the Pearson correlation coefficient to understand the influence of miRNAs and their targets. The results of miRNAs showing Pearson correlation coefficient with its corresponding miRNA target of more than 0.9 is given in Table 6. However, the expression profiles of all the miRNAs were not perfectly negative to its corresponding targets.

\section{Discussion \\ Strategies to reveal the disease-resistant mechanism of mango ginger}

Ginger, a herbaceous tropical perennial crop, belongs to the family Zingiberaceae [20]. Among the diseases that affect ginger, bacterial wilt caused by $R$. solanacerum is one of the major production constraints in several regions of the world [21]. Even though there are several released varieties in ginger, none of them is resistant to $R$. solanacearum infection due to lack of genetic variability. Among the primary and secondary gene pool, the mango ginger ( $C$. amada) exhibited immune response to $R$. solanacearum [22]. Initially, PR5 genes in ginger and mango ginger were cloned, and their expression was analyzed to understand their role in disease resistance [23]. Later, number of candidate genes were identified based on transcriptome-wide sequencing of ginger and mango ginger under bacterial wilt [10]. Moreover, a web source was generated, which provides public access to the ginger and mango ginger transcriptome database. Here, we employed the same RNA-Seq data to identify the miRNAs and their targets in two ginger species upon $R$. solanacearum infection. Also, to determine the differential expression and regulation of miRNAs and their targets. The study is expected to deliver several insights in understanding the miRNA regulatory network in ginger and mango ginger against R. solanacearum.

\section{Differential expression and functional annotation of DEmiRTGs}

A total of 4736 and 4485 DEmiRTGs were identified in ginger and mango ginger in response to $R$. solanacearum 
Table 3 Primers designed to perform qPCR experiments with the shortlisted nine miRNAs

\begin{tabular}{lll}
\hline miRnA & Stem loop primer & Forward primer \\
\hline osa-miR169 & GTTGGCTCTGGTGCAGGGTCCGAGGTATTCGCACCAGAGCCAAC GAATGG & GTGGGCATCATCCATCCTA \\
ppt-miR1223 & GTTGGCTCTGGTGCAGGGTCCGAGTATTCGCACCAGAGCCAACTAGAGG & GGGGTTGTAGAGTCATGCA \\
aly-miR398 & GTTGGCTCTGGTGCAGGGTCCAGGTATCGCACCAGAGCCAAC CATATG & GTTGGGGTCGACATGAGAA \\
gra-miR482 & GTCGTATCCAGTGCAGGGTCCGAGGTATTCGCACTGGATACGACTTGGAA & AACACGCTTCCCAAAACCTC \\
gma-miR4415 & GTTGGCTCTGGTGCAGGGTCCGAGGTATTCGCACCAGAGCCAAC CCATGT & GTTTGGGTTGATTCTCATCACA \\
mtr-miR5261 & GTTGGCTCTGGTGCAGGGTCCGAGGTATTCGCACCAGAGCCAACAGCCAA & GGGGTCATTGTAGATGGCT \\
ath-miR167 & GTTGGCTCTGGTGCAGGGTCCGAGGTATTCGCACCAGAGCCAAC CCAGAT & GTTTGAAGCTGCCAGCATG \\
ath-miR1886 & GTTGGCTCTGGTGCAGGGTCCGAGGTATTCGCACCAGAGCCAACTTTTCT & GGGGTGAGAAGAAGAAGA \\
mtr-miR164 & GTTGGCTCTGGTGCAGGGTCCGAGGTATTCGCACCAGAGCCAACTGCACG & GTTTGGAGAAGCAGGGCA \\
Reverse common & GTCGTATCCAGTGCAGGGT & \\
\hline
\end{tabular}

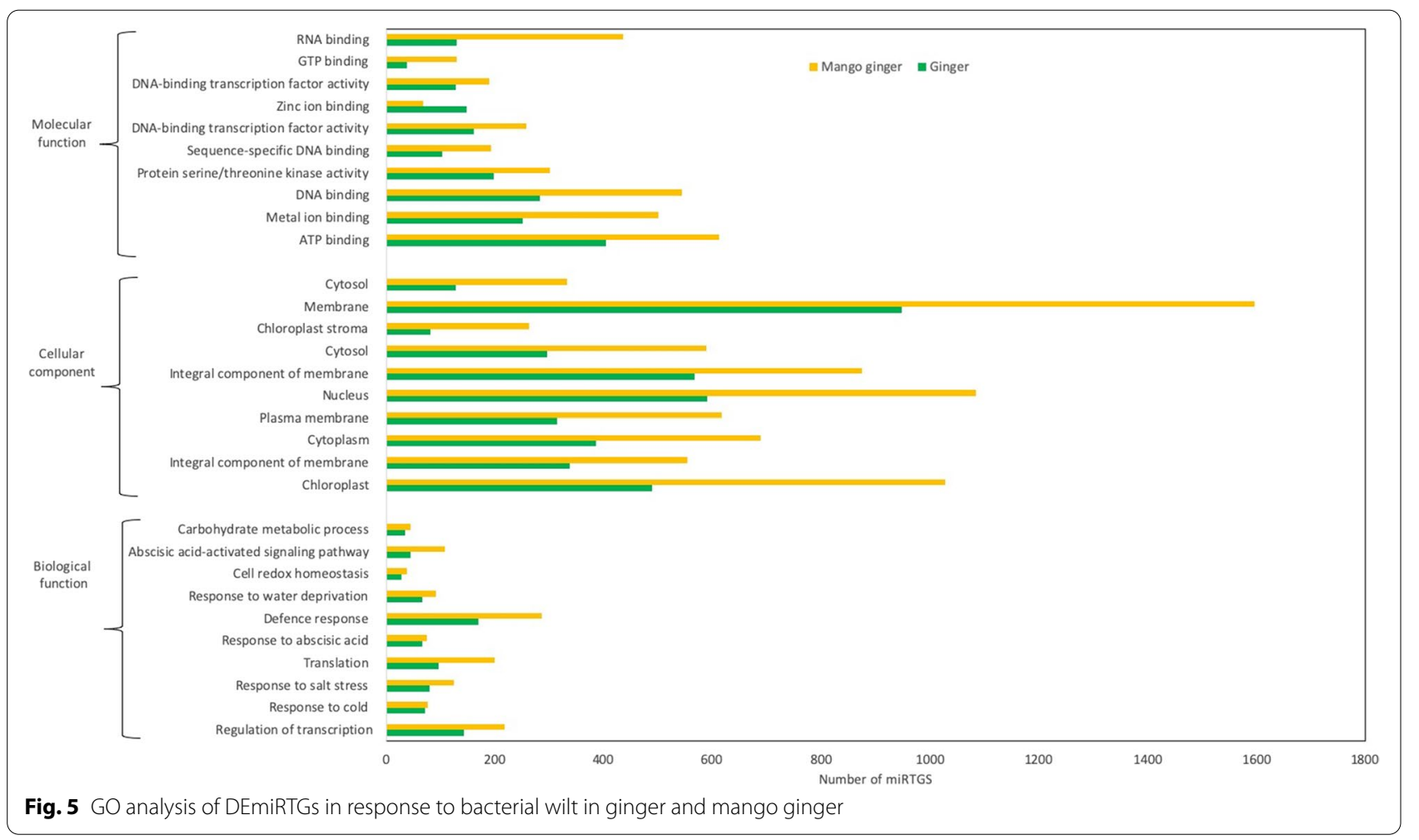

(Fig. 1). Functional annotation results showed that the term "defence response" had higher enrichment in mango ginger than ginger. Among the upregulated common miRTGs and miRTGs exclusively expressed in mango ginger, maximum enrichment was observed in the "defence response". Moreover, there were 215 miRTGs which was upregulated in mango ginger but downregulated in ginger. Among them 23 GO terms were related to "defence response". Also "defence response towards bacterium" was the major GO term in all cases. The GO analysis clearly revealed the activation and higher expression of several defencerelated proteins, especially defence response proteins towards bacterium in resistant ginger. KEGG pathway analysis showed that carbohydrate metabolism terms in mango ginger were higher when compared to ginger. It was previously reported that carbohydrate metabolism was disturbed during $R$. solanacearum infection in tomato [24]. A well-established activation of carbohydrate metabolism pathway genes may be one reason for bacterial wilt resistance in mango ginger. 
Table 4 Differential expressed defense related miRTGs in response to Ralstonia solanacearum

\begin{tabular}{|c|c|c|c|c|}
\hline Gene annotation & No. of genes & $\begin{array}{l}\text { Ginger } \\
\text { upregulated }\end{array}$ & $\begin{array}{l}\text { Mango ginger } \\
\text { upregulated }\end{array}$ & Target genes \\
\hline Abscisic acid signalling & 7 & 2 & 2 & $\begin{array}{l}\text { FERON_ARATH, UBA2A_ARATH, EDR1_ARATH, } \\
\text { CDPKS_ARAT }\end{array}$ \\
\hline Activation of protein kinase & 4 & 2 & 4 & M3K3A_ARATH \\
\hline Autophagosome assembly & 1 & 0 & 0 & ATG7_ARATH \\
\hline Brassinosteroid mediated signaling pathway & 1 & 1 & 1 & GLO1_ARATH \\
\hline Defense response to bacterium & 13 & 12 & 13 & $\begin{array}{l}\text { Y2766_ARATH, WRK53_ARATH, POP3_ARATH, NPR2 } \\
\text { ORYSJ, SIR4_ARATH, P2C59_ARATH, RENT3_ARATH, } \\
\text { BAHL2_ORYSI, CRK25_ARATH }\end{array}$ \\
\hline Cellular response to jasmonic acid & 7 & 3 & 7 & HNRPQ_ARATH \\
\hline Cellular response to osmotic stress & 1 & 1 & 1 & NTL9_ARATH \\
\hline Cellular response to water deprivation & 2 & 2 & 2 & CP41B_ARATH \\
\hline Ceramide biosynthetic process & 2 & 2 & 2 & IPCS_ORYSJ \\
\hline Defense response & 24 & 14 & 24 & $\begin{array}{l}\text { LRR2_ARATH, PBL17_ARATH, ERG1_ORYSJ, DRL17_- } \\
\text { ARATH, WRK19_ARATH, PBL19_ARATH, PBL3_ARATH, } \\
\text { PBL16_ARATH, EDR2L_ARATH, LRKS5_ARATH, RPS2_- } \\
\text { ARATH, DGK5_ARATH, ERF82_ARATH, MKP1_ARATH, } \\
\text { LRR1_ARATH }\end{array}$ \\
\hline Defense response to fungus & 7 & 4 & 7 & $\begin{array}{l}\text { CML36_ARATH, BBD1_ARATH, PRT6_ARATH, C3H47_ } \\
\text { ARATH }\end{array}$ \\
\hline Carbohydrate metabolism process & 2 & 2 & 2 & E1314_ARATH \\
\hline Ethylene signaling pathway & 4 & 3 & 4 & EDR2_ARATH \\
\hline
\end{tabular}

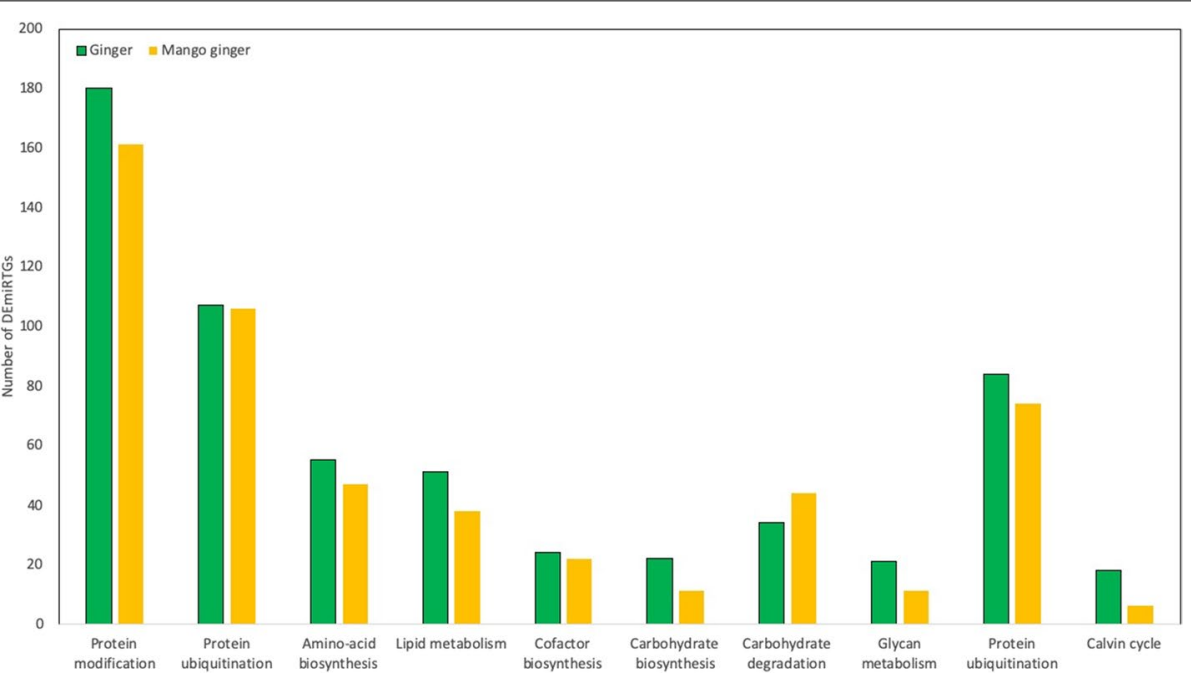

Fig. 6 KEGG pathway analysis of DEmiRTGs in response to bacterial wilt in ginger and mango ginger

Table 5 List of upregulated and downregulated genes

\begin{tabular}{lll}
\hline & Upregulated & Downregulated \\
\hline Ginger leaves & $4 C C L$, ABCC5, PRT6, RPS2, FRS6, WRKY19, DNAJ1 & AAP4, ABCG11 \\
Mango ginger leaves & $4 C C L$, ABCC5, PRT6, RPS2, AAP4, ABCG11 & FRS6, WRKY19, DNAJ1 \\
Ginger rhizome & $4 C C L$, ABCC5, PRT6, RPS2, FRS6, WRKY19, DNAJ1, ABCG11 & AAP4 \\
Mango ginger rhizome & $4 C C L$, ABCC5, PRT6, RPS2, DNAJ1, ABCG11, AAP4 & FRS6, WRKY19 \\
\hline
\end{tabular}




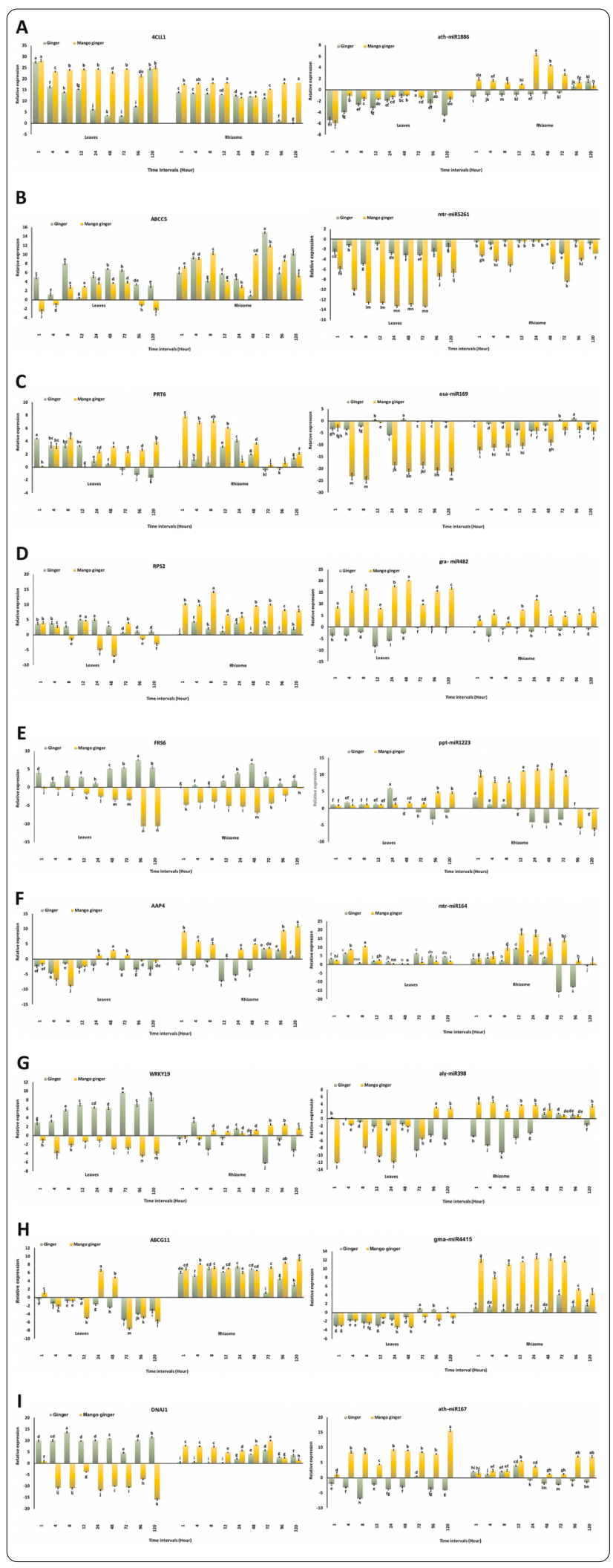

Fig. 7 Normalized relative gene expression levels of nine miRNAs and targets in ginger and mango ginger leaf and rhizome tissues at different time intervals post inoculation with $R$. solanacearum. $\mathbf{A}$ 4CLL1 \& ath-miR1886, B ABCC5 \& mtr-miR5261, C PRT6 \& osa-miR169, D RPS2 \& gra-miR482, E FRS6 \& ppt-miR1223, F AAP4 \& mtr-miR164, G WRKY19 \& aly-miR398, H ABCG11 \& gma-miR4415 and I DNAJ1 \& ath-miR167. Values are the means \pm standard deviation of three independent experiments involving three replicates. Values superscripted with the different letters are significantly different based to Tukey's HSD at $P \leq 0.05$

Validation of differentially expressed selected miRTGs This study mainly focused on the identification miRTGs, and their potential miRNAs involved in regulating bacterial wilt defence reactions. We have selected nine miRTGs and validated their expression. These selected miRTGs were previously reported to have a significant role in plant-pathogen interaction during biotic stress.

4CLL (4-coumarate-CoA ligase) is considered an essential component in the phenylpropanoid pathway [25]. It primarily participates in the biosynthesis of p-coumaroyl-CoA, a precursor biosynthesis of several plant metabolites, including coumarin [26]. Coumarin accumulation is considered one of the most critical responses in infection with various viruses, fungi, and pathogens $[27,28]$. The role of coumarin in defence response against $R$. pseudosolanacearum infection in tobacco has been reported previously [29]. In our study, the expression of 4-coumarate-CoA ligase (4CLL1) was upregulated in ginger and mango ginger during bacterial wilt infection. Moreover, the expression levels were higher in mango ginger compared to ginger in both tissues. This clearly shows the role of this gene during bacterial wilt (Fig. 7A).

Though initially identified as transporters that play in detoxification processes, later $\mathrm{ABC}$ transporters were shown to be required in stress responses, pathogen interaction [30]. In the present study, we compared the expression of two $\mathrm{ABC}$ transporter genes, $\mathrm{ABCC} 5$ and $\mathrm{ABCC} 11$, during bacterial wilt among ginger species. ABCC5 encodes a high-affinity inositol Hexa kis phosphate transporter, which plays a part in guard cell signalling and phytate storage [31]. This protein was reported to play a role in the defence mechanism in several plants [31,32]. ABCC11 has reported being involved in developmental plasticity and stress responses [33]. $\mathrm{ABCC} 5$ and $\mathrm{ABCC} 11$ were differentially expressed among resistant and susceptible gingers. However, their expression was more evident in rhizome than leaves in both ginger species. Since bacterial wilt is a rhizome borne disease in ginger, these genes may play a critical role in disease resistance (Fig. 7B \& H). Similarly, a difference in expression of $A B C$ transporter genes was shown in Solanum sps when Globodera pallida infected resistant and susceptible plant roots [34]. 
Table 6 Correlation analysis of miRNAs expression profiles and their target genes in response to Ralstonia solanacearum

\begin{tabular}{lllllll}
\hline Target gene & Protein & Selected miRNA & \multicolumn{2}{l}{ Pearson correlation coefficient } \\
\cline { 5 - 7 } & & & Ginger leaves & Ginger rhizome & $\begin{array}{l}\text { Mango ginger } \\
\text { leaves }\end{array}$ & $\begin{array}{l}\text { Mango } \\
\text { ginger } \\
\text { rhizome }\end{array}$ \\
\hline RPS2 & & & & & -0.92 & -0.90 \\
FRS6 & NBS-LRR & miR482 & -0.94 & -0.92 & -9.99 & -0.91 \\
ABCC5 & FAR1-related sequence 6 & miR-1223 & -0.92 & -0.91 & -0.97 & -0.95 \\
PRT6 & ABC transporter & miR-5261 & -0.94 & -0.91 & -0.95 & -0.98 \\
ABCG11 & Ubiquitin protein ligase & miR-169 & -0.95 & -0.98 & -0.97 & -0.94 \\
AAP4 & ABC transporter & miR-4415 & -0.97 & -0.97 & -0.97 & -0.93 \\
DNAJ1 & Amino acid-proton symporter & miR-164 & 0.90 & -0.91 & -0.95 & -0.97 \\
WRKY19 & Heat shock protein & miR-167 & -0.93 & -0.94 & -0.97 & -0.90 \\
4CLL1 & Transcription factor & miR-398 & -0.912 & -0.98 & -0.91 & -0.97 \\
\hline
\end{tabular}

PRT6 is a ubiquitin-protein ligase that is a component of the $\mathrm{N}$-end rule pathway. It regulates the biosynthesis of plant-defence metabolites such as glucosinolates, and phytohormone jasmonate which play a crucial role in plant immunity [35]. In our experiment, PRT6 had higher expression in mango ginger leaves and rhizome tissues when compared to ginger (Fig. 7C). PRT6 mutants in Arabidopsis also showed higher susceptibility than wild type when infected with $R$. solanacearum [35].

NBS-LRR genes are one of the most studied disease resistance gene family in plants [36]. Several studies have been carried out in these genes in giving resistance in wheat, cassava, sugarcane, rice, apple, coconut [37, 38]. They are involved in detecting various biotic stresses such as pathogens, including bacteria, viruses, fungi, nematodes, insects, and oomycetes. Their action can lead to plant cell death in the typical hypersensitive response [39]. We compared the expression of an NBS-LRR protein, RPS2, which was also well characterized in other plants $[40,41]$. There was a significant difference in the expression of RPS2 in mango ginger when compared to ginger (Fig. 7D). Moreover, the expression was higher in rhizome when compared to leaves. It was reported earlier that overexpression of RPS2 activates a downstream defence response pathway in Arabidopsis [42].

FRS6 (FAR1-related sequence 6) is a protein essential for phytochrome A controlled far-red responses in Arabidopsis. Loss-of-function mutants display elongated hypocotyls, specifically under continuous FR light (FRc) [43]. It was reported that during heat stress, this gene was downregulated in conic seagrass, Posidonia oceanica [44]. In agreement with previous reports, the FRS6 was downregulated in resistant ginger and upregulated in susceptible ginger (Fig. 7E).

AAP4 is an amino acid permease which is an amino acid-proton symporter. It is a stereospecific transporter and has broad specificity for neutral amino acids, such as alanine, asparagine, and glutamine. It was reported that amino acid transporters play a crucial role in plant defence by controlling amino acid transport [45, 46]. Significantly differential expression of AAP4 among tissues and ginger species was observed in our experiment (Fig. 7F). Thus, amino acid transporter might have a significant role in defence response against $R$. solanacearum.

WRKY19 is a transcription factor that acts as a disease resistance protein with a serine/threonine-protein kinase activity [47]. The TIR-NB-LRR pair DSC1 and WRKY19 contributed to basal immunity in Arabidopsis against the root-knot nematode Meloidogyne incognita [48]. Also, overexpression of wheat WRKY gene TaWRKY19 increased the salt, drought, and freezing tolerance in transgenic plants [49]. Our study showed high expression in ginger leaves when compared to mango ginger (Fig. 7G). Nevertheless, in the case of the rhizome, higher expression of WRKY 19 was observed in mango ginger. Thus, WRKY19 might have some critical role in defence response.

DNAJ1 are heat shock proteins (HSPs) that are molecular chaperones known for controlling inappropriate aggregation, folding, misfolding, and unfolding several proteins. They are reported to be involved in hyperosmotic and heat shock by preventing the aggregation of stress-denatured proteins and disaggregating proteins [50]. In this study, DNAJ1 was differentially expressed among different tissues of ginger species (Fig. 7I). These results proved its role in defence is tissue-specific and different in ginger species.

\section{Comparison and validation of expression of selected miRNAs}

Several reports of plant miRNA involvement in regulating signalling pathways, NBS-LRR gene expression, and 
ROS pathways during pathogen infestation are available. Here we studied the role of nine miRNAs during bacterial wilt in susceptible and resistant ginger species. As mentioned earlier, even though each miRTGs had targets for several miRNAs, data of miRNAs showing Pearson correlation coefficient with its corresponding miRNA target of more than 0.9 were only analyzed.

miR1886 was found to play an important role in abiotic and biotic stress in various plants. miR1886 was less expressed in response to ABA treatment related to an increase in Cf4CL transcripts [51]. In this study, athmiR1886 targeted 4CLL1 in ginger and mango ginger. Ath-miR1886 was upregulated in mango ginger rhizome and downregulated in ginger leaves and rhizomes. This suggests that it is tissue-specific and species-specific. However, the expression difference among ginger species was a strong indication of miR1886's role in bacterial wilt resistance (Fig. 7A).

Several extended studies were carried out to understand the role of miRNA mediated regulation of $A B C$ transporters. Here we studied mtr-miR5261 and gmamiR4415, which targets ABCC5 and ABCG11, respectively. Both miRNAs were previously reported to play defence response during biotic and abiotic stress [52-54]. Even though both miRNAs were expressed differentially among ginger species, gma-miR4415 seems to play effectively in defence against bacterial wilt since its expression was 10 to 20 times higher in rhizome than leaves of resistant one (Fig. 7B\&H).

Osa-miR169, which targets PRT6, is a conserved miRNA family reported in plant growth, development and responses induced by stress. In rice, osa-miR169 negatively regulate the immune response against blast fungus, Magnaporthe oryzae. It proved that regulation was made by repressing the expression of nuclear transcription factor subunit alpha (NF-YA) genes. Moreover, osa-miR169 overexpressed transgenic rice lines were hyper susceptible to M. oryzae infection [55]. Our study clearly showed that osa-miR169 was down-regulated in both ginger and mango ginger, but less expression in ginger than mango ginger (Fig. 7C). Also, downregulation of this miRNA in the early stages proves its crucial role during $R$. solanacerum infection.

Gra-miR482 is an ancient and extensive family of miRNA present in all land plants. In cotton, it regulated the target site by cleaving and inhibiting the expression of target nucleotide-binding sites and leucine-rich repeat (NBS-LRR) [56]. In this study, the gra-miR482 mainly targets RPS2. Gra-miR482 was down-regulated in leaves and rhizomes of ginger but upregulated in mango ginger, even in the initial hours of the infection (Fig. 7D). These results imply that miR482 regulates the defence response of the NBS-LRR gene in ginger species.
Ppt-miR1223 targets mainly genes related to nucleic acid binding and secondary metabolic process. In ginger it targets mainly FRS6. miR1223 was reported previously in Allium cepa [57] and Physcomitrella patens [58]. This miRNA upregulated in the rhizome of both ginger and mango ginger, till $12 \mathrm{~h}$ post-infection (Fig. 7E). However, later this miRNA was down regulated in ginger rhizomes, indicating its role during the early phase of infection. Several miRNAs showed a differential expression in the early and late phase of the disease [59].

Mtr-miR164 was conserved, highly expressed in fruits, and validated to target a subset of the NACdomain transcription factor gene family such as AAP4 [60, 61]. Aly-miR398 was a conserved miRNA identified in Arabidopsis which targets WRKY19 [62]. Both were expressed tissue specifically and more in the rhizomes of resistant ginger compared to susceptible one (Fig. 7F \&G). However, the role played by these miRNAs on disease resistance or susceptibility is not clearly understood.

The ath-miR167 was reported to be important in correcting gene expression patterns and fertility in both ovules and anthers in Arabidopsis [63]. In this study it cleaved DNAJ1. Among the ginger species, the higher expression in mango ginger revealed its vital role in resistance (Fig. 7I).

\section{Conclusions}

Our study utilized the already available RNA-Seq data to identify and compare DEmiRTGs and their miRNAs in ginger and mango ginger against $R$. solanacearum. This strategy aided in developing a new miRNA seq data of 4736 and 4485 DEmiRTGs in ginger and mango ginger, respectively. Functional annotation results showed that several defence response terms were enriched specifically in resistant ginger. KEGG analysis revealed the crucial role of carbohydrate metabolism during bacterial wilt infection in ginger. Additionally, we identified nine miRNA/miRTGs key candidate pairs in response to $R$. solanacearum infection in ginger. Our results paved the way in understanding significant miRNA-mediated posttranscriptional regulation of bacterial wilt resistance in mango ginger. The data set generated is further helpful in exploring miRNAs function in improving ginger resistance to bacterial wilt.

\section{Methods \\ miRNA target and miRNA prediction}

To evaluate miRNAs' role in response to bacterial wilt infection in ginger (susceptible) and mango ginger (resistant), we have used already available RNA-Seq data of ginger (PRJNA311170), and mango ginger (PRJNA315599) 
challenged with Ralstonia. The leaf tissues of three biological replicates were sampled over a $72 \mathrm{~h}$ period postinoculation and pooled before RNA preparation. The two RNA libraries were constructed and sequenced using Illumina RNA-Seq method [64]. After sequencing, highquality reads were retained after removing the adapter, low-quality sequences and PCR duplicates from the raw data using FASTQ Quality Check [65].

Those clean reads were utilized here to reconstruct the transcriptome de novo. Trinity-v2.11.0 software with the parameters: minimum contig length of 100 bases and average fragment length $300 \mathrm{bp}$ was used [66]. These two predicted transcriptome data were utilized to predict conserved miRTGs and identify the miRNAs for each target. Both were carried out using the psRNATarget server [67]. In this research, the following default parameters were used for identifying potential miRTGs: (1) maximum expectation 3; (2) length for complementarity scoring (hsp size) 20; (3) target accessibility-allowed maximum energy to unpair the target site (UPE) 25; (4) flanking length around target site for target accessibility analysis 17 bp upstream and 13 bp downstream and (5) range of central mismatch leading to translational inhibition 9-11 nucleotides. For the prediction of miRNAs for each miRTGs, above mentioned psRNATarget server was used with default parameters.

\section{Differential expression and functional analysis}

Differential expression was conducted using edgeR [68] with significant miRTGs based on FDR-corrected $p$-value $<=0.05$. The number of reads mapped and Reads Per Kilobase of the transcript, per Million mapped reads (RPKM) were used to calculate fold change (FC). Transcripts with $\mathrm{FC}>=0.8$ and $P$ value $<=0.05$ was considered as upregulated and $\mathrm{FC}<=-0.8$ and $P$ value $<=0.05$ were considered as downregulated. Blast2GO software with default settings was used in Gene Ontology (GO) annotation and KEGG (Kyoto Encyclopedia of Genes and Genomes) pathway analysis to identify the putative biological functions and pathways of the DEmiRTGs. Initially, BLASTX aligned $(\mathrm{E} \leq 1 \mathrm{e}-6)$ contigs to the NCBI non-redundant protein database and later $\mathrm{GO}$ terms were retrieved for each BLAST hit with default parameters. KEGG maps were also retrieved for each query sequence as per instructions [69].

\section{Construction of regulatory network using miRNA-mRNA}

Visualization of the regulatory network between miRNA and mRNA was constructed using Cytoscape 3.7.1 [70].

\section{Plant material}

For experimental validation, ginger (susceptible) and mango ginger (resistant) varieties used were IISR Varada and Amba, respectively. Disease-free rhizomes were obtained from the Experimental Farm of ICAR-Indian Institute of Spices Research, Peruvannamuzhi, Kerala, India. Sterile distilled water was used to wash the rhizome thoroughly. They were then planted in autoclaved perlite. The plants were maintained in the net house of the ICAR-Indian Institute of Spices Research, Kozhikode, Kerala.

\section{Inoculum preparation and inoculation procedure}

Initially, fresh cultures $R$. solanacearum strain GRs Mnt2 (virulent) grown using Casamino acid-Peptone-Glucose (CPG) medium were inoculated in CPG broth kept at $28{ }^{\circ} \mathrm{C}$ for $16 \mathrm{~h}$ with continuous shaking. Forty-five-day old, same sized plants were carefully removed from perlite and washed. Plants were incubated for five days in a beaker containing $150 \mathrm{ml}$ virulent broth under greenhouse conditions. Similarly, fresh plants were maintained in sterile water as control. Plant tissues (leaves and rhizome) were collected form different time intervals post-inoculation $(1,4,8,12,24,48,72,96$, and 120 -h post-inoculation (hpi)).

\section{Expression validation of using $\mathrm{qPCR}$}

Here quantitative RT-PCR (qRT-PCR) was performed to validate the expression of miRTGs and miRNAs on the Rotor-Gene Q real-time PCR system (Qiagen, USA). For each sample, there were three biological replicates. Stemloop qRT-PCR [71] for miRNA and regular qPCR [72] for target genes were conducted as described previously. The fold change of the transcripts was calculated relative to the control ( 0 hpi) using the $2^{- \text {ddCt }}$ method using $\beta$-actin as an internal control. List of primers used are available in Tables 2 and 3.

\section{Statistical analysis}

To evaluate the statistical validity of results, all experiments were performed three times, each having five replicates. IBM SPSS Statistics 24 was used for statistical analysis. Data shown are the mean value \pm standard deviation of three independent experiments. One way ANOVA along with Tukey posthoc test at $P<0.05$ level of significance was carried out. Correlation analysis between selected miRNAs and their targets were carried out using the Pearson coefficient.

\section{Abbreviations}

miRNA: MicroRNA; DEmiRTG: Differentially expressed miRNA target gene; miRTGs: MiRNA target genes; Zo: Zingiber officinale; Ca: Curcuma amada; $R$. solanacearum: Ralstonia solanacearum. 


\section{Supplementary Information}

The online version contains supplementary material available at https://doi. org/10.1186/s12870-021-03108-0.

Additional file 1. List of miRTGs with their corresponding miRNAs.

\section{Acknowledgements}

We Acknowledge, National Postdoctoral Fellowship (SERB), India for funding and ICAR-Indian Institute of Spices Research, Kozhikode, Kerala, India for all support in carrying out this work.

\section{Authors' contributions}

The first author, SM has carried out Conceptualization, Methodology, Investigation, Statistical analysis, Writing-Original draft preparation. The corresponding author, DP has done Conceptualization, Resources, Validation, Supervision, Writing-Reviewing and Editing. The author(s) read and approved the final manuscript.

\section{Funding}

The present work was funded by Science and Engineering Research Board, Indian under the scheme National Postdoctoral Fellowship (Project number PDF/2017/000072). The funders had no role in the experimental design, data analysis, decision to publish, or preparation of the manuscript.

\section{Availability of data and materials}

The RNA-seq data used in this study was available through the NCBI under accession number PRJNA315599 (mango ginger) and PRJNA311170 (ginger) We have a permission to collect the plant samples we used in this study. All the data and materials that are required to reproduce these findings can be shared by contacting the corresponding author, Duraisamy Prasath (Prasa th.D@icar.gov.in).

\section{Declarations}

Ethics approval and consent to participate Not applicable.

\section{Consent for publication}

Not applicable.

\section{Competing interests}

There is no competing interest among the authors.

Received: 25 March 2021 Accepted: 11 June 2021

Published online: 29 July 2021

\section{References}

1. Ravindran PN, Sasikumar B, George JK. Genetic resources of ginger (Zingiber officinale Rosc.) and its conservation in India. Plant Genet Resour Newsl. 1994:98:1-4.

2. Kumar A, Sarma YR. Characterization of Ralstonia solanacearum causing bacterial wilt in ginger. Indian Phytopathol. 2012;57:524-6.

3. Bag BB. Ginger processing in India (Zingiber officinale): a review. Int J Curr Microbiol App Sci. 2018;7:1639-51.

4. Champoiseau PG, Jones JB, Allen C. Ralstonia solanacearum Race 3 Biovar 2 causes tropical losses and temperate anxieties. Plant Health Prog. 2009:10:35.

5. Ghosh PP, Mandal NC. Some disease management practices for bacterial wilt of potato. J Plant Prot Sci. 2009:1:51-4

6. Peeters N, Guidot A, Vailleau F, Valls M. Ralstonia solanacearum, a widespread bacterial plant pathogen in the post-genomic era. Mol Plant Pathol. 2013;14:651-62.

7. Turner M, Jauneau A, Genin S, Tavella M-J, Vailleau F, Gentzbittel L, et al. Dissection of bacterial wilt on Medicago truncatula revealed two type III secretion system effectors acting on root infection process and disease development. Plant Physiol. 2009;150:1713-22.
8. Kumar A, Sarma YR, Anandaraj M. Evaluation of genetic diversity of Ralstonia solanacearum causing bacterial wilt of ginger using REP-PCR and PCR-RFLP. Curr Sci. 2004;87:1555-61.

9. Hong Y, Liu S, Zhu Y, Xie C, Jue D, Chen M, et al. Expression of the MSI$99 \mathrm{~m}$ gene in transgenic potato plants confers resistance to Phytophthora infestans and Ralstonia solanacearum. Plant Mol Biol Rep. 2013;31:418-24.

10. Prasath D, Karthika R, Habeeba NT, Suraby EJ, Rosana OB, Shaji A, et al. Comparison of the transcriptomes of ginger (Zingiber officinale Rosc.) and mango ginger (Curcuma amada Roxb.) in response to the bacterial wilt infection. PLoS One. 2014;9:e99731.

11. Sunkar R, Zhu J-K. Novel and stress-regulated microRNAs and other small RNAs from Arabidopsis. Plant Cell. 2004;16:2001-19.

12. Ramachandran SR, Mueth NA, Zheng P, Hulbert SH. Analysis of miRNAs in two wheat cultivars infected with Puccinia striiformis f. sp. tritici. Front Plant Sci. 2020;10. https://doi.org/10.3389/fpls.2019.01574.

13. Shriram V, Kumar V, Devarumath RM, Khare TS, Wani SH. MicroRNAs as potential targets for abiotic stress tolerance in plants. Front Plant Sci. 2016;7. https://doi.org/10.3389/fpls.2016.00817.

14. Zhang X, Bao Y, Shan D, Wang Z, Song X, Wang Z, et al. Magnaporthe oryzae Induces the expression of a microRNA to suppress the immune response in rice. Plant Physiol. 2018;177:352-68.

15. Xin $M$, Wang $Y$, Yao $Y, X i e ~ C$, Peng $H, N i$, et al. Diverse set of microRNAs are responsive to powdery mildew infection and heat stress in wheat (Triticum aestivum L.). BMC Plant Biol. 2010;10:123.

16. Hunt M, Banerjee S, Surana P, Liu M, Fuerst G, Mathioni S, et al. Small RNA discovery in the interaction between barley and the powdery mildew pathogen. BMC Genom. 2019:20:610.

17. Fahim M, Millar AA, Wood CC, Larkin PJ. Resistance to wheat streak mosaic virus generated by expression of an artificial polycistronic microRNA in wheat. Plant Biotechnol J. 2012;10:150-63.

18. Kis A, Tholt G, Ivanics M, Várallyay É, Jenes B, Havelda Z. Polycistronic artificial miRNA-mediated resistance to wheat dwarf virus in barley is highly efficient at low temperature. Mol Plant Pathol. 2016;17:427-37.

19. Sun L, Lin C, Du J, Song Y, Jiang M, Liu H, et al. Dimeric artificial microRNAs mediate high resistance to RSV and RBSDV in transgenic rice plants. Plant Cell Tiss Organ Cult. 2016;126:127-39.

20. Vasala PA. 18 - Ginger. In: Peter KV, editor. Handbook of herbs and spices (Second Edition). Woodhead Publishing; 2012. p. 319-35. https://doi.org/ 10.1533/9780857095671.319.

21. Guji MJ, Yetayew HT, Kidanu ED. Yield loss of ginger (Zingiber officinale) due to bacterial wilt (Ralstonia solanacearum) in different wilt management systems in Ethiopia. Agric Food Secur. 2019:8:5.

22. Kumar A, Bhai S, Sasikumar B. Curcuma amada Roxb. A bacterial wilt evading species in Zingiberaceae- A potential source of valuable genes for bacterial wilt resistance. In: The 4th international bacterial wilt symposium. York: The Lakeside Conference Centre, Central Science Laboratory; 2006

23. Prasath D, El-Sharkawy I, Sherif S, Tiwary KS, Jayasankar S. Cloning and characterization of PR5 gene from Curcuma amada and Zingiber officinale in response to Ralstonia solanacearum infection. Plant Cell Rep. 2011:30:1799-809.

24. Ishihara T, Mitsuhara I, Takahashi H, Nakaho K. Transcriptome analysis of quantitative resistance-specific response upon Ralstonia solanacearum infection in tomato. PLoS One. 2012;7:e46763.

25. Matern U. Coumarins and other phenylpropanoid compounds in the defense response of plant cells. Planta Med. 1991;57(7 Suppl):S15-20.

26. Stringlis IA, de Jonge R, Pieterse CMJ. The age of coumarins in plantmicrobe interactions. Plant Cell Physiol. 2019;60:1405-19.

27. Li Y, Kim Jl, Pysh L, Chapple C. Four isoforms of Arabidopsis 4-coumarate: CoA ligase have overlapping yet distinct roles in phenylpropanoid metabolism. Plant Physiol. 2015;169:2409-21.

28. Am B. Evolution and current status of research in phenolic compounds. Phytochem. 2007;68. https://doi.org/10.1016/j.phytochem.2007.06.012.

29. Yang L, Wu L, Yao X, Zhao S, Wang J, Li S, et al. Hydroxycoumarins: New, effective plant-derived compounds reduce Ralstonia pseudosolanacearum populations and control tobacco bacterial wilt. Microbiol Res. 2018;215:15-21.

30. Kang J, Park J, Choi H, Burla B, Kretzschmar T, Lee Y, et al. Plant ABC transporters. Arabidopsis Book. 2011. p. 9. https://doi.org/10.1199/tab.0153.

31. Klein M, Perfus-Barbeoch L, Frelet A, Gaedeke N, Reinhardt D, MuellerRoeber $\mathrm{B}$, et al. The plant multidrug resistance ABC transporter AtMRP5 
is involved in guard cell hormonal signalling and water use. Plant $\mathrm{J}$. 2003;33:119-29.

32. Remy E, Cabrito TR, Baster P, Batista RA, Teixeira MC, Friml J, et al. A major facilitator superfamily transporter plays a dual role in polar auxin transport and drought stress tolerance in Arabidopsis. Plant Cell. 2013;25:901-26.

33. Alvarado MC, Zsigmond LM, Kovács I, Cséplö Á, Koncz C, Szabados LM. Gene trapping with firefly luciferase in Arabidopsis. Tagging of stressresponsive genes. Plant Physiol. 2004:134:18-27.

34. Kooliyottil R, Dandurand L-M, Kuhl JC, Caplan A, Xiao F, Mimee B, et al. Transcriptome analysis of Globodera pallida from the susceptible host Solanum tuberosum or the resistant plant Solanum sisymbriffolium. Sci Rep. 2019;9. https://doi.org/10.1038/s41598-019-49725-6.

35. de Marchi R, Sorel M, Mooney B, Fudal I, Goslin K, Kwaśniewska K, et al. The $\mathrm{N}$-end rule pathway regulates pathogen responses in plants. Sci Rep. 2016;6. https://doi.org/10.1038/srep26020

36. Jones DA, Jones JDG. The role of leucine-rich repeat proteins in plant defences. In: Andrews JH, Tommerup IC, Callow JA, editors. Advances in botanical research. Academic; 1997. p. 89-167. https://doi.org/10.1016/ S0065-2296(08)60072-5.

37. Bozkurt O, Hakki EE, Akkaya MS. Isolation and sequence analysis of wheat NBS-LRR type disease resistance gene analogs using degenerate PCR primers. Biochem Genet. 2007:45:469-86.

38. Lozano R, Hamblin MT, Prochnik S, Jannink J-L. Identification and distribution of the NBS-LRR gene family in the Cassava genome. BMC Genom. 2015;16:360.

39. Belkhadir Y, Subramaniam R, Dangl JL. Plant disease resistance protein signaling: NBS-LRR proteins and their partners. Curr Opin Plant Biol. 2004;7:391-9.

40. Chelkowski J, Tyrka M, Sobkiewicz A. Resistance genes in barley (Hordeum vulgare L.) and their identification with molecular markers. J Appl Genet. 2003:44:291-310.

41. Joshi RK, Kar B, Mohanty S, Subudhi E, Nayak S. Molecular cloning, characterization, and expression analysis of resistance gene candidates in Kaempferia galanga L. Mol Biotechnol. 2012;50:200-10.

42. Mackey D, Belkhadir Y, Alonso JM, Ecker JR, Dangl JL. Arabidopsis RIN4 is a target of the type III virulence effector AvrRpt2 and modulates RPS2mediated resistance. Cell. 2003;112:379-89.

43. Lin $\mathrm{R}$, Wang H. Arabidopsis FHY3/FAR1 gene family and distinct roles of its members in light control of Arabidopsis development. Plant Physiol. 2004;136:4010-22.

44. Marín-Guirao L, Entrambasaguas L, Ruiz JM, Procaccini G. Heatstress induced flowering can be a potential adaptive response to ocean warming for the iconic seagrass Posidonia oceanica. Mol Ecol. 2019;28:2486-501.

45. Fischer WN, Kwart M, Hummel S, Frommer WB. Substrate specificity and expression profile of amino acid transporters (AAPs) in Arabidopsis. J Biol Chem. 1995;270. https://doi.org/10.1074/jbc.270.27.16315.

46. Yang $G$, Wei $Q$, Huang $H$, Xia J. Amino acid transporters in plant cells: a brief review. Plants. 2020;9:967.

47. Eulgem T, Rushton PJ, Robatzek S, Somssich IE. The WRKY superfamily of plant transcription factors. Trends Plant Sci. 2000;5:199-206.

48. Warmerdam S, Sterken MG, Sukarta OCA, van Schaik CC, Oortwijn MEP, Lozano-Torres JL, et al. The TIR-NB-LRR pair DSC1 and WRKY19 contributes to basal immunity of Arabidopsis to the root-knot nematode Meloidogyne incognita. BMC Plant Biol. 2020;20:73.

49. Niu C-F, Wei W, Zhou Q-Y, Tian A-G, Hao Y-J, Zhang W-K, et al. Wheat WRKY genes TaWRKY2 and TaWRKY19 regulate abiotic stress tolerance in transgenic Arabidopsis plants. Plant Cell Environ. 2012;35:1156-70.

50. Jia T, Li F, Liu S, Dou J, Huang T. DnaJ proteins regulate WUS expression in shoot apical meristem of Arabidopsis. Plants (Basel). 2021;10. https://doi. org/10.3390/plants10010136.

51. Awasthi P, Mahajan V, Jamwal VL, Chouhan R, Kapoor N, Bedi YS, et al. Characterization of the gene encoding 4-coumarate: CoA ligase in Coleus forskohlii. J Plant Biochem Biotechnol. 2019;28:203-10.

52. Gul Z, Barozai MYK, Din M. In-silico based identification and functional analyses of miRNAs and their targets in Cowpea (Vigna unguiculata L.) AIMS Genet. 2017:4:138-65.

53. Abla M, Sun H, Li Z, Wei C, Gao F, Zhou Y, et al. Identification of miRNAs and their response to cold stress in Astragalus Membranaceus. Biomolecules. 2019;9. https://doi.org/10.3390/biom9050182.
54. Kulcheski F, Manavella P, Weigel D, Margis R. The role of MIR4415 in soybean response to asian soybean rust infection. BioTechnologia J Biotechnol Comput Biol Bionano. 2013;94. http://agro.icm.edu.pl/agro/ element/bwmeta1.element.agro-cf900e6a-3528-4856-86c7-90b2553005 ea. Accessed 23 Sept 2020.

55. Li Y, Zhao S-L, Li J-L, Hu X-H, Wang H, Cao X-L, et al. Osa-miR169 negatively regulates rice immunity against the blast fungus Magnaporthe oryzae. Front Plant Sci. 2017;8. https://doi.org/10.3389/fpls.2017.00002.

56. Zhu Q-H, Fan L, Liu Y, Xu H, Llewellyn D, Wilson I. miR482 regulation of NBS-LRR defense genes during fungal pathogen infection in cotton. PLoS One. 2013;8. https://doi.org/10.1371/journal.pone.0084390.

57. Mishra R, Mohapatra R, Mahanty B, Joshi RK. Analysis of microRNAs and their targets from onion (Allium cepa) using genome survey sequences (GSS) and expressed sequence tags (ESTs). Bioinformation. 2019;15:907-17.

58. Talmor-Neiman M, Stav R, Klipcan L, Buxdorf K, Baulcombe DC, Arazi T. Identification of trans-acting siRNAs in moss and an RNA-dependent RNA polymerase required for their biogenesis. Plant J. 2006;48:511-21.

59. Rajwanshi R, Devi KJ, Sharma GR, Lal B. Role of miRNAs in plant-microbe interaction. In: In vitro plant breeding towards novel agronomic traits: Biotic and abiotic stress tolerance. Singapore: Springer; 2019. p. 167-95. https://doi.org/10.1007/978-981-32-9824-8_10.

60. Hernandez Y, Goswami K, Sanan-Mishra N. Stress induced dynamic adjustment of conserved miR164:NAC module. Plant Environ Interact. 2020:1:134-51.

61. Rosas Cárdenas FDF, Ruiz Suárez Y, Cano Rangel RM, Luna Garcia V, González Aguilera KL, Marsch Martínez N, et al. Effect of constitutive miR164 expression on plant morphology and fruit development in Arabidopsis and tomato. Agronomy. 2017;7:48.

62. Jones-Rhoades MW, Bartel DP. Computational identification of plant microRNAs and their targets, including a stress-induced miRNA. Mol Cell. 2004;14:787-99.

63. Wu M-F, Tian Q, Reed JW. Arabidopsis microRNA167 controls patterns of ARF6 and ARF8 expression, and regulates both female and male reproduction. Development. 2006:133:4211-8.

64. Fu N, Wang Q, Shen H-L. De novo assembly, gene annotation and marker development using Illumina paired-end transcriptome sequences in celery (Apium graveolens L.). PLoS One. 2013;8:e57686.

65. Roser LG, Agüero F, Sánchez DO. FastqCleaner: an interactive bioconductor application for quality-control, filtering and trimming of FASTQ files. BMC Bioinformatics. 2019;20:361.

66. Grabherr MG, Haas BJ, Yassour M, Levin JZ, Thompson DA, Amit I, et al. Trinity: reconstructing a full-length transcriptome without a genome from RNA-Seq data. Nat Biotechnol. 2011;29:644-52.

67. Dai X, Zhuang Z, Zhao PX. psRNATarget: a plant small RNA target analysis server (2017 release). Nucleic Acids Res. 2018;46:W49-54.

68. Robinson MD, McCarthy DJ, Smyth GK. edgeR: a Bioconductor package for differential expression analysis of digital gene expression data. Bioinformatics. 2010;26:139-40.

69. Conesa A, Götz S, García-Gómez JM, Terol J, Talón M, Robles M. Blast2GO: a universal tool for annotation, visualization and analysis in functional genomics research. Bioinformatics. 2005;21:3674-6.

70. Shannon P, Markiel A, Ozier O, Baliga NS, Wang JT, Ramage D, et al. Cytoscape: a software environment for integrated models of biomolecular interaction networks. Genome Res. 2003;13:2498-504.

71. Yang L, Wang S, Tang L, Liu B, Ye W, Wang L, et al. Universal stem-loop primer method for screening and quantification of microRNA. PLoS One. 2014:9:e115293.

72. Mohandas S, Venugopal V, Duraisamy P. Understanding the expression of signalling pathway marker genes associated with bacterial wilt in susceptible and resistant ginger sps. Physiol Mol Plant Pathol. 2021;115:101666.

\section{Publisher's Note}

Springer Nature remains neutral with regard to jurisdictional claims in published maps and institutional affiliations. 